\title{
COMPLICATIONS OF LONG BONE FRACTURE HEALING IN DOGS: FUNCTIONAL AND RADIOLOGICAL CRITERIA FOR THEIR ASSESSMENT
}

\author{
M. DVOŘ́́K, A. NEČAS, J. ZATLOUKAL \\ Small Animal Clinic, Faculty of Veterinary Medicine, University of Veterinary and Pharmaceutical Sciences, \\ Brno, Czech Republic \\ Received May 19, 2000 \\ Accepted June 13, 2000
}

\begin{abstract}
Dvořák M., A. Nečas, J. Zatloukal: Complications of Long Bone Fracture Healing in Dogs. Functional and Radiological Criteria for Their Assessment. Acta Vet. Brno 2000, 69: 107-114.

The goal of our study was not only to detect the incidence of both minor and major complications in the long bone fracture treatment in dogs, but also establish a rate of radiographically apparent complications which can be functionally tolerable for the patients. The clinical records of $200 \mathrm{dogs}$ with fractures of long bones of the limbs treated at the Clinic of Surgery and Orthopedics at University of Veterinary and Pharmaceutical Sciences in Brno from the beginning of January 1998 through the end of June 1999 were reviewed. Fracture management was performed in 156 dogs with 164 fractures. These fractures were treated by open ( $86.59 \%$ cases) or closed $(13.41 \%)$ reductions and internal fixation $(70.73 \%)$, external skeletal fixation $(25.61 \%)$, and external coaptation $(3.66 \%)$ Two groups of clinical patients were created. Group I consisted of 64 dogs with outcome information obtained from a questionnaire. The results of treatment in this group were excellent in $70.31 \%$ cases, very good in $21.88 \%$, and fair in $7.81 \%$. In group II, 92 dogs having 100 long bone fractures with complete follow-up information obtained from clinical and radiological examinations at our clinic were included. The results of therapy in group II were excellent totally in $81.00 \%$ cases, very good in $12.00 \%$, fair in $1.00 \%$, and poor in $6.00 \%$. Complications of fracture healing in this group II were assessed. The complications were found mainly in cases with an interval between injury and fracture fixation longer than 4 days $\left(\chi^{2}\right.$-test; $p<0.01$ ). Clinically sound dogs (with excellent result of therapy) were able to functionally tolerate radiographic abnormalities in consequence of fracture treatment in $44.45 \%$ cases ( 36 of 81 fractures with excellent outcome of therapy).

Fracture, bone healing, nonunion, delayed union, incidence, dog
\end{abstract}

Fractures of the long bones of extremities are common in dogs (Johns on et al. 1994). The primary goal of any fracture treatment is to restore the function of the injured limb as soon as possible and completely (Brinker et al. 1984). A variety of fracture treatment options exists, including internal fixation with open reduction (Brinker et al. 1984; Huls e 1997; Nečas 1996), external skeletal fixation with open or closed reduction (Johns on et al. 1998a; Johnson et al. 1998b; Aron and Toombs 1984), miniinvasive percutaneous insertion of Kirschner wires (Gál and Nečas 1999), and external coaptation (De Camp 1993). Selection of the method of fixation depends on fracture configuration, the size and age of the animal, biological considerations, the number of limbs involved, concurrent musculoskeletal injuries, and financial resources of the client. The last but not least factor determining the method of repair is familiarity of the surgeon with the equipment and techniques.

Complications may occur with each type of fracture fixation. Some complications are "acceptable" not only for the surgeon, but also the animal. Minor complications such as slight malalignment (which does not require repositioning) and hypertrophic callus are not so serious clinical problems. On the other hand, major complications, including delayed union and nonunion, severe malalignment (requiring repositioning), osteomyelitis and implant failure are in numerous cases considered as fatal sequelae.

Address for correspondence:

Doc. MVDr. Alois Nečas, Ph.D.

Clinic of Surgery and Orthopedics

Palackého 1-3, 61242 Brno, Czech Republic
Phone: +420602742484

http://www vfu cz/acta-vet/actavet htm 
Studies on fracture management in small animals use different scales evaluating the results of treatment. Some authors evaluate the outcome of surgery using a more complex classification with radiographic characteristics (Meyer-Lindenberg et al. 1991), others use only or mainly functional criteria (Guerin et al. 1998, Stigen 1999).

The goal of our study was to detect the incidence of both minor and major complications in the long bone fracture treatment in dogs, evaluate possible discrepancies between the functional and radiographical outcomes in this treatment, and to establish a rate of radiographically evident minor and major complications of bone healing which the clinical patients can functionally tolerate.

\section{Materials and Methods}

The clinical records of 200 dogs with fractures of long bones of the limbs (humerus, radius/ulna, femur, tibia) treated at the Clinic of Surgery and Orthopedics at University of Veterinary and Pharmaceutical Sciences in Brno from the beginning of January 1998 through the end of June 1999 were reviewed and evaluated. Forty-four of these patients died during the perioperative period, were euthanatized, or were not managed, because of financial insolvency of the owner and were lost to our follow-up. Fracture management underwent $156 \mathrm{dogs}$. The age, breed, sex, total number of long bone fractures, their incidence in the affected bones of extremities, type of fracture (closed versus open), type and localization of fracture line, type of reduction, method of fracture fixation, and the time from injury to fracture fixation were recorded and analysed in these 156 clinical patients. Each dog received a standard diagnostic evaluation, including orthopedic and radiographic examinations. The injured bones were radiographed using mediolateral and craniocaudal, or caudocranial views, respectively.

Dogs were treated according to the principles of AO/ASIF using open or closed reductions and different types of internal and/or external skeletal fixations, or external coaptation. The method of fracture repair was selected depending on the fracture-patient assessment score (Hulse and Johnson 1999), and financial resources of the owner. The fracture management was performed by two experienced orthopedic surgeons. Animals were hospitalised from 2 to 16 days in our clinic receiving standard postoperative care. The dogs were returned to our clinic at four to eight weeks after treatment for follow-up orthopedic and radiographic examination. Next follow-up examinations were carried out at four to six weeks intervals, if needed. Searching for necessary data (functional and radiographical aspects of the fracture treatment were included), we used clinical records on hospitalised patients, and outpatients, respectively. Long bone fractures were classified using a system described by Unger et al. (1990). In cases of physeal injury, classification according to Salter-Harris (1963) was used. Long-term follow up was obtained by examination of the dog at our hospital when feasible, or by a questionnaire when not. Owners were asked to describe the extent of functional recovery that was evident in the dog and the time at which this was noted following fracture repair. Residual intermittent lameness, persistent lameness, and non-weightbearing lameness were also recorded. Patients were observed for at least 9 months after surgery ( $9-27$ months follow-up). Based on the completeness of the follow-up information two groups of clinical patients were created. Group I consisted of 64 dogs with outcome information obtained from the questionnaire. Results of treatment in this group were classified according to only functional criteria as excellent (no lameness), very good (temporary, intermittent weightbearing lameness), fair (permanent weightbearing lameness) and poor (non-weightbearing lameness). In group II, 92 dogs with complete follow-up information obtained from clinical and radiological examinations at our clinic were included. Modified evaluation of treatment results presented by Meyer-Lindenberg et al. (1991) was used in group II and results of the therapy were classified as excellent both functionally and radiographically (no lameness; healed fracture radiologically in full alignment with the bone axis; no signs of arthrosis in the surrounding joints), excellent functionally (no lameness, however, radiologically apparent complications in fracture healing and/or signs of arthrosis in the surrounding joints), very good (temporary, intermittent weightbearing lameness; radiologically apparent complications in fracture healing and/or signs of arthrosis in the surrounding joints), fair (permanent weightbearing lameness; radiologically detected complications in fracture healing and/or signs of arthrosis in the surrounding joints) and poor (non-weightbearing lameness; radiologically detected complications in fracture healing and/or signs of arthrosis in the surrounding joints). Complications of fracture fixation in this group of clinical patients were assessed. Minor complications were defined as slight malalignment (which does not require repositioning), hypertrophic callus, mild arthrosis in the surrounding joints and delayed union of the fracture. A delayed union was defined as a fracture which has failed to heal within an anticipated period (Robins 1998). Major complications included severe malalignment (requiring repositioning), severe arthrosis in the surrounding joints, nonunions, osteomyelitis and implant failure. A nonunion fracture was defined as a fracture which has failed to heal (Robins 1998). We determined the number of radiographic abnormalities in cases of fractures with excellent outcome of surgery that were functionally torelated by the dogs.

Mean and standard deviation were calculated for age of the animals. The breed predisposition and outcome of fracture management depending on the method of fixation, affected bone, type of fracture (closed versus open), fracture line, type of reduction (open versus closed), accuracy of fragment reposition, and the time from injury to fracture fixation were tested using $\chi^{2}$-test. Statistical analyses were done using Stat plus 1.10 (Matoušková et al. 1992). 


\section{Results}

The incidence of long bone fractures of the limb (200 clinical cases) in a population of 5,222 dogs seen at our hospital from the beginning of January 1998 till the end of June 1999 was assessed (3.83\% of total surgical patient number). Forty-nine breeds of dogs, including mongrels, were represented in the 156 clinical patients with long bone fractures of extremities. Mongrels $(21.79 \%)$ were the most commonly affected in our study, followed by German Shepherd (5.13\%), Yorkshire Terrier (3.21\%), Dalmatian (3.85\%), Staffordshire Terrier (3.21\%), Fox Terrier (1.92\%), Miniature Pinscher (1.92\%), Piccolo Levriero Italiano (1.28\%), Papillon (1.28\%). Predisposition to fractures of long bones of the limbs was confirmed in all these breeds using $\chi^{2}$-test $(p<0.05)$. The age of the dogs varied from two months to 14 years with an average of $2.03 \pm 2.52$ years. Ninety-five dogs $(60.90 \%)$ were males and sixty-one $(39.10 \%)$ were females.

The total number of long bone fractures found in our 156 patients was 164 . The most commonly broken bones were radius and ulna (28.66\% of long bone fractures), followed by tibia and fibula $(28.05 \%)$, femur $(25.00 \%)$ and humerus $(18.29 \%)$. One hundred and fifty long bone fractures were closed $(91.46 \%$ cases) and fourteen fractures were open $(8.54 \%$ cases). These 164 long bone fractures were characterized by following localization and type of fracture line: diaphyseal complex (26.83\%), diaphyseal transverse $(25.61 \%)$, metaphyseal and/or physeal and/or epiphyseal extraarticular (17.07\%), metaphyseal and/or physeal and/or epiphyseal intraarticular (15.85\%), and diaphyseal oblique or spiral $(14.64 \%)$. Type of reduction was open in 142 cases ( $86.59 \%$ long bone fractures) and closed in 22 cases $(13.41 \%)$. These fractures were treated using internal fixation $(70.73 \%$ long bone fractures), external skeletal fixation $(25.61 \%)$, and external coaptation $(3.66 \%)$. The time from injury to fracture fixation ranged from day 0 (day of injury) to day 90 (mean $+\mathrm{SD}$ 5.0412.53 days; median 2 days).

The results of treatment in 64 dogs of group I were excellent in $70.31 \%$ of these dogs (45 cases), very good in $21.88 \%$ ( 14 cases), and fair in $7.81 \%$ ( 5 cases). The results of treatment in 92 dogs with 100 long bone fractures of group II were excellent in $81.00 \%$ of these fractures ( 81 fractures), including excellent functionally and radiographically in $45.00 \%$ (45 fractures), excellent functionally in $36.00 \%$ (36 fractures). Very good results of treatment in group II were achieved in $12.00 \%$ of these fractures (12 long bone fractures), fair in $1.00 \%$ ( 1 fracture), and poor in $6.00 \%$ (6 fractures).

Table 1 shows radiographically apparent complications and/or combinations of the complications in long bone fracture cases with functionally excellent outcome in group II. All complications and/or combinations of the complications in long bone fracture cases with very good, fair, and poor outcomes are presented in Table 2.

No significant differences were found between outcome of fracture treatment and variables such as sex, age of the animal, affected bone, and the fracture line. Dependence between the outcome of fracture management and type of reduction (open versus closed) in the group II was confirmed $\left(\chi^{2}\right.$-test; $\left.p<0.01\right)$. Evaluating open reposition compared to closed reposition significant difference between fracture cases with functionally and radiographically excellent outcome of therapy (no lameness; healed fracture radiologically in full alignment with the bone axis; no signs of arthrosis in the surrounding joints) and cases with functionally excellent outcome (no lameness, however radiologically complications in fracture healing and/or signs of arthrosis in the surrounding joints) was found by $\left(\chi^{2}\right.$-test $p<0.01)$. At the $5 \%$ level of significance, dependence between results of therapy and the time from injury to fracture fixation was confirmed. Concerning dependence on the time from injury to fracture management, significant difference between fracture cases with functionally and radiographically excellent outcome and functionally excellent outcome was found $\left(\chi^{2}\right.$-test; $\left.p<0.01\right)$. Significant difference $\left(\chi^{2}\right.$-test; $\left.p<0.05\right)$ in results of fracture 
Table 1

Radiographically apparent complications and/or combinations of these complications of long bone fractures in 36 cases with functionally excellent outcome of therapy

\begin{tabular}{|c|c|c|c|c|c|c|c|c|c|c|c|c|}
\hline 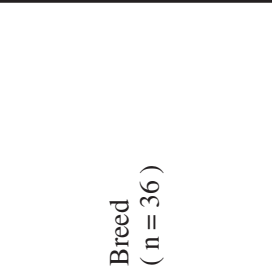 & 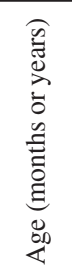 & \begin{tabular}{l}
$*$ \\
\multirow{2}{*}{} \\
$\frac{1}{0}$ \\
$Z$ \\
$S$
\end{tabular} & 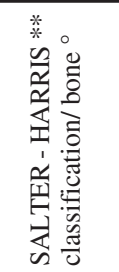 & 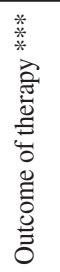 & 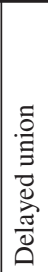 & 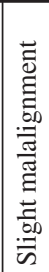 & 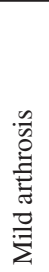 & 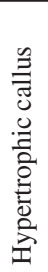 & 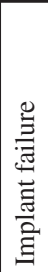 & 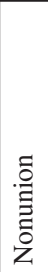 & 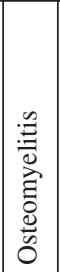 & 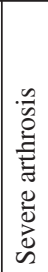 \\
\hline Mongrel & $2,5 \mathrm{y}$ & $12 \mathrm{C} 3$ & & $\mathrm{EF}$ & $\mathrm{x}$ & & & & & & & \\
\hline Toy Poodle & $4 \mathrm{~m}$ & & IV. (DH) & $\mathrm{EF}$ & & $\mathrm{x}$ & & & & & & \\
\hline Toy Poodle & $4 \mathrm{~m}$ & & IV. (DH) & $\mathrm{EF}$ & & $\mathrm{x}$ & & & & & & \\
\hline Labrador Retriever & $1 \mathrm{y}$ & $13 \mathrm{~B} 1$ & & $\mathrm{EF}$ & & & & & $\mathrm{x}$ & & & \\
\hline Cocker Spaniel & $5 \mathrm{~m}$ & & II. (DH) & $\mathrm{EF}$ & & $\mathrm{x}$ & $\mathrm{x}$ & & $\mathrm{x}$ & & & \\
\hline Dachshund & $2 \mathrm{y}$ & $21 \mathrm{~A} 3$ & & $\mathrm{EF}$ & & & & $\mathrm{x}$ & & & & \\
\hline Mongrel & $6 \mathrm{~m}$ & $22 \mathrm{~A} 2$ & & $\mathrm{EF}$ & & & & $\mathrm{x}$ & & & & \\
\hline Yorkshire Terrier & $6 \mathrm{~m}$ & $22 \mathrm{~A} 2$ & & $\mathrm{EF}$ & & $\mathrm{x}$ & & $\mathrm{x}$ & & & & \\
\hline Bernese Mountain Dog & $8 \mathrm{~m}$ & $22 \mathrm{C} 1$ & & $\mathrm{EF}$ & $\mathrm{x}$ & & & & & & & \\
\hline Miniature Pinscher & $6 \mathrm{~m}$ & $22 \mathrm{~A} 2$ & & $\mathrm{EF}$ & & & $\mathrm{x}$ & & & & & \\
\hline Cocker Spaniel & $4 \mathrm{y}$ & $22 \mathrm{~B} 2$ & & $\mathrm{EF}$ & & $\mathrm{x}$ & & & & & & \\
\hline Miniature Poodle & $3 y$ & $22 \mathrm{~A} 2$ & & $\mathrm{EF}$ & $\mathrm{x}$ & & & & & & & \\
\hline Miniature Schnauzer & $6 y$ & $22 \mathrm{~A} 2$ & & $\mathrm{EF}$ & & $\mathrm{x}$ & & & & & & \\
\hline Mongrel & $7 \mathrm{~m}$ & $22 \mathrm{~A} 2$ & & EF & & & & $\mathrm{x}$ & & & & \\
\hline Cocker Spaniel & $6 \mathrm{~m}$ & $22 \mathrm{~A} 1$ & & $\mathrm{EF}$ & & & & $\mathrm{x}$ & & & & \\
\hline Mongrel & $2,5 \mathrm{y}$ & $22 \mathrm{~A} 2$ & & $\mathrm{EF}$ & & $\mathrm{x}$ & & $\mathrm{x}$ & & & & \\
\hline Mongrel & $6 y$ & & II. (DF) & $\mathrm{EF}$ & & $\mathrm{x}$ & & & & & & \\
\hline Czech Hunting Dog & $1 \mathrm{y}$ & $32 \mathrm{~A} 2$ & & $\mathrm{EF}$ & $\mathrm{x}$ & & & & & & & \\
\hline Dalmatian & $7 y$ & $32 \mathrm{~A} 3$ & & $\mathrm{EF}$ & $\mathrm{x}$ & & & & & & & \\
\hline Welsh Terrier & $1,5 \mathrm{y}$ & $32 \mathrm{C} 3$ & & $\mathrm{EF}$ & $\mathrm{x}$ & & & & & & & \\
\hline Mongrel & $3 \mathrm{y}$ & $32 \mathrm{~B} 2$ & & $\mathrm{EF}$ & $\mathrm{x}$ & & & & & & & \\
\hline Staffordshire Terrier & $8 \mathrm{~m}$ & $32 \mathrm{C} 3$ & & $\mathrm{EF}$ & & & & $\mathrm{x}$ & & & & \\
\hline Boxer & $4 \mathrm{~m}$ & $32 \mathrm{~B} 1$ & & $\mathrm{EF}$ & & & & $\mathrm{x}$ & & & & \\
\hline German Pointer & $6 \mathrm{~m}$ & $32 \mathrm{~A} 3$ & & $\mathrm{EF}$ & $\mathrm{x}$ & & & $\mathrm{x}$ & & & & \\
\hline Dachshund & $7 \mathrm{~m}$ & & II. (DF) & $\mathrm{EF}$ & $\mathrm{x}$ & $\mathrm{x}$ & & & & & & \\
\hline Giant Schnauzer & $3 \mathrm{~m}$ & & II. (DF) & $\mathrm{EF}$ & & & & $\mathrm{x}$ & & & & \\
\hline Dachshund & $1 \mathrm{y}$ & $42 \mathrm{~A} 2$ & & $\mathrm{EF}$ & & & & $\mathrm{x}$ & & & & \\
\hline Dachshund & $14 \mathrm{y}$ & $42 \mathrm{~A} 2$ & & $\mathrm{EF}$ & $\mathrm{x}$ & & & & & & & \\
\hline Mongrel & $9 \mathrm{~m}$ & $42 \mathrm{C} 3$ & & $\mathrm{EF}$ & & & & $\mathrm{x}$ & & & & \\
\hline Mongrel & $5 y$ & $42 \mathrm{~A} 3$ & & $\mathrm{EF}$ & & $\mathrm{x}$ & & & & & & \\
\hline Mongrel & $6 \mathrm{~m}$ & $42 \mathrm{~A} 3$ & & $\mathrm{EF}$ & & & & $\mathrm{x}$ & & & & \\
\hline Mongrel & $2 \mathrm{y}$ & $42 \mathrm{~B} 3$ & & $\mathrm{EF}$ & & & & $\mathrm{x}$ & & & & \\
\hline Standard Poodle & $9 \mathrm{y}$ & $42 \mathrm{~A} 2$ & & $\mathrm{EF}$ & $\mathrm{x}$ & & & $\mathrm{x}$ & & & $\mathrm{x}$ & \\
\hline Mongrel & $6 \mathrm{~m}$ & $42 \mathrm{~A} 3$ & & $\mathrm{EF}$ & & & & $\mathrm{x}$ & & & & \\
\hline Hovawart & $4 y$ & $42 \mathrm{C} 3$ & & $\mathrm{EF}$ & & $\mathrm{x}$ & & $\mathrm{x}$ & & & & \\
\hline Bullterrier & $2 \mathrm{~m}$ & $42 \mathrm{~B} 1$ & & $\mathrm{EF}$ & & & & $\mathrm{x}$ & & & & \\
\hline
\end{tabular}

Explanations:

* Classification of long bone fractures according to Unger et al. (1990)

** Classification of physeal fractures according to Salter-Harris (1963)

*** EF- excellent functionally

DH- distal humeral physis

DF- distal femoral physis 
Table 2

Radiographically apparent complications and/or combinations of these complications of long bone fractures in 19 cases with very good, fair and poor outcomes of therapy

\begin{tabular}{|c|c|c|c|c|c|c|c|c|c|c|c|c|}
\hline 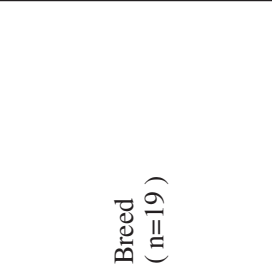 & 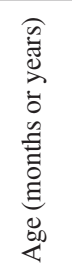 & 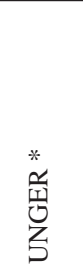 & 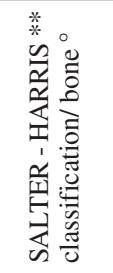 & 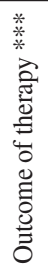 & 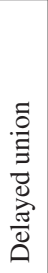 & 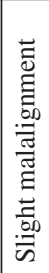 & 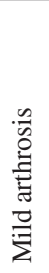 & 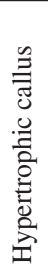 & 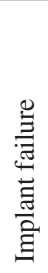 & 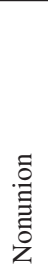 & 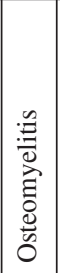 & 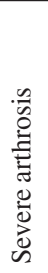 \\
\hline German Shepherd & $3 y$ & $13 \mathrm{~B} 2$ & & V & & & $\mathrm{x}$ & & & & & \\
\hline Mastiff & $1 \mathrm{y}$ & $13 \mathrm{~B} 1$ & & $\mathrm{~V}$ & & & & & & & & $\mathrm{x}$ \\
\hline Miniature Pinscher & $6 \mathrm{~m}$ & $22 \mathrm{~A} 2$ & & $\mathrm{~V}$ & & $\mathrm{x}$ & $\mathrm{x}$ & & & & & \\
\hline Irish Terrier & $7 y$ & $22 \mathrm{~A} 1$ & & $\mathrm{~V}$ & $\mathrm{x}$ & & & $\mathrm{x}$ & $\mathrm{x}$ & & & \\
\hline Bernese Mountain Dog & $8 \mathrm{~m}$ & $22 \mathrm{C} 3$ & & $\mathrm{~V}$ & & $\mathrm{x}$ & & $\mathrm{x}$ & & & & \\
\hline Mongrel & $5,5 \mathrm{y}$ & $22 \mathrm{~B} 1$ & & $\mathrm{~V}$ & $\mathrm{x}$ & & & & & & & $\mathrm{x}$ \\
\hline Yorkshire Terrier & $9 \mathrm{~m}$ & $23 \mathrm{~A} 2$ & & V & $\mathrm{x}$ & & $\mathrm{x}$ & & & & & \\
\hline Doberman Pinscher & $4 y$ & $42 \mathrm{~A} 3$ & & V & $\mathrm{x}$ & $\mathrm{x}$ & & & & & & \\
\hline Dachshund & $3 \mathrm{~m}$ & $42 \mathrm{C} 3$ & & $\mathrm{~V}$ & & $\mathrm{x}$ & & & & & & \\
\hline Boxer & $3 \mathrm{~m}$ & $42 \mathrm{~A} 3$ & & V & & $\mathrm{x}$ & & $\mathrm{x}$ & & & & \\
\hline Yorkshire Terrier & $5 \mathrm{~m}$ & $23 \mathrm{~A} 3$ & & V & & $\mathrm{x}$ & & & & & & \\
\hline Dachshund & $9 \mathrm{y}$ & $12 \mathrm{C} 3$ & & $\mathrm{~F}$ & $\mathrm{x}$ & & & & & & & $\mathrm{x}$ \\
\hline Staffordshire Terrier & $4 \mathrm{~m}$ & & IV. (DH) & $\mathrm{P}$ & & $\mathrm{x}$ & & & & & $\mathrm{x}$ & \\
\hline Mongrel & $4 y$ & $13 \mathrm{C} 3$ & & $\mathrm{P}$ & $\mathrm{x}$ & & & & & & $\mathrm{x}$ & $\mathrm{x}$ \\
\hline Yorkshire Terrier & $2 y$ & $32 \mathrm{C} 3$ & & $P$ & & & & & & $\mathrm{x}$ & & \\
\hline Mongrel & $8 \mathrm{y}$ & $13 \mathrm{C} 2$ & & $P$ & & & & & $\mathrm{x}$ & $\mathrm{x}$ & & \\
\hline Dalmatian & $4 \mathrm{~m}$ & & I. (PF) & $\mathrm{P}$ & & & & & $\mathrm{x}$ & $\mathrm{x}$ & & \\
\hline Dalmatian & $4 \mathrm{~m}$ & $32 \mathrm{C} 3$ & & $\mathrm{P}$ & & & & & & & $\mathrm{x}$ & \\
\hline
\end{tabular}

Explanations:

* Classification of long bone fractures according to Unger et al. (1990) ** Classification of physeal fractures according to Salter-Harris (1963)

*** V-very good

F- fair

P- poor

DH- distal humeral physis

PF- proximal femoral physis

management depending on type of fracture (closed versus open) was found between fractures with functionally and radiographically excellent outcome and functionally excellent outcome. We confirmed significant difference $\left(\chi^{2}\right.$-test; $\left.p<0.01\right)$ evaluating dependence of outcome of treatment on accuracy of fragment reposition between fracture cases with functionally and radiographically excellent outcome and cases with functionally excellent outcome.

\section{Discussion}

In nine of 49 breeds of dogs, including mongrels, represented in our clinical sample of patients predisposition to long bone fractures of the limbs was confirmed $\left(\chi^{2}\right.$-test; $\left.p<0.05\right)$. The age of the dogs varied from 2 months to 14 years (mean $2.03 \pm 2.52$ years). Both sex, and age of dogs in our heterogeneous clinical sample concerning the age of animals (immature dogs ( $\leq 1$ year of age); mature ( $>1$ year of age)) did not significantly influence parameters analysed in our study (the method of fixation, affected bone, type of fracture 
(closed versus open), fracture line, type of reduction (open versus closed), accuracy of fragment reposition, and the time from injury to fracture fixation) in dependence on outcome of fracture management.

In all, 8 dogs from 156 patients had two limbs broken simultaneously. Distribution of 164 fractures of long bones of the extremities among radius and ulna $(28.66 \%$ long bone fractures), tibia and fibula $(28.05 \%)$, femur $(25.00 \%)$ and humerus $(18.29 \%)$ was nearly equal. Closed fractures predominated $(91.46 \%$ cases $)$ in our study. Open fractures $(8.97 \%$ cases) were diagnosed entirely in bones below elbow or stifle joints. Because of lucidity of information and ability to analyse the data generated, we used classification as proposed by Unger et al. (1990). It was easy to apply to majority of fracture types and localization. In our opinion, this classification can improve comparability of different treatment techniques if it becomes widely used and data is recorded in a central data bank. However, we can sustain the idea (Meyer-Lindenberg et al. 1991) that other findings influencing prognosis such as soft tissue damage or differentiation between closed and open fractures are not included in the system of fracture classification. Some inconsistencies in classifying long bone fractures were found similar to the experience of other authors (Miller et al. 1998). For simplicity, localization and type of fracture line in our clinical patients can be summarized as follows: diaphyseal complex (26.83\%), diaphyseal transverse $(25.61 \%)$, metaphyseal and/or physeal and/or epiphyseal extraarticular (17.07\%), metaphyseal and/or physeal and/or epiphyseal intraarticular (15.85\%), and diaphyseal oblique or spiral $(14.64 \%)$.

When selecting the method of fracture treatment for given long bone fracture we considered both fracture patient assessment score (Hulse and Johnson 1999) and financial resources of the client. We attempted to avoid any possible complication (Gál 1999; Gál et al. 1999). The most frequent management of these fractures was internal fixation $(70.73 \%$ fractures), followed by external skeletal fixation $(25.61 \%)$, and external coaptation (3.66\%). This fact influenced the ratio of open ( $86.59 \%$ long bone fractures) and closed reductions in our study. Dependence between the outcome of fracture management and the type of reduction (open versus closed) in group II was confirmed ( $\chi^{2}$-test; $p<0.01$ ). Evaluation of open reposition as compared to closed reposition revealed significant difference between fracture cases with functionally and radiographically excellent outcome of therapy and cases with functionally excellent outcome $\left(\chi^{2}\right.$-test, $\left.p<0.01\right)$.

Supposed that dogs are able to functionally tolerate some pathological changes we decided to quantify possible clinically non apparent complications of fracture healing. We tightened the criteria commonly used to classify the results of fracture management (Guerin et al. 1998; Stigen 1999; Whitney and Schrader 1987) in an attempt to fullfil our goal and to reveal possible "obscure" radiographically apparent complications of fracture healing in dogs without lameness after long bone fracture treatment. Therefore we had to divide 156 treated dogs into two groups according to availability of complete follow-up information. The outcome of treatment in group I (64 dogs in which results of treatment were assessed by sending questionnaires to the owner) was excellent in $70.31 \%$ cases (no lameness), very good in $21.88 \%$ (temporary, intermittent weightbearing lameness), and fair in $7.81 \%$ (permanent weightbearing lameness). There was not a single poor outcome in this group of patients (nonweightbearing lameness). The results of treatment in group II (92 dogs with 100 long bone fractures) were excellent in $81.00 \%$ fracture cases, including outcome excellent functionally and radiographically in $45.00 \%$ (no lameness; no radiographically apparent complication of fracture healing), excellent functionally in $36.00 \%$ (no lameness; defined radiographically apparent complications of fracture healing). Comparing the results of therapy in dogs with excellent outcomes (81 cases of fractures), it is possible to conclude that $44.45 \%$ (36 cases) of these long bone fractures were accompanied by different radiographically apparent 
complications (Table 1), which were functionally tolerated by the dogs. These patients were clinically sound. Videlicet, an excellent outcome of long bone fracture management from the point of view of the owner does not necessarily concur with that of the clinician. Radiologically detected complications such as delayed union, slight axial malalignment of bone fragments, mild arthrosis in adjacent joint, hyperthrophic callus, implant failure, and osteomyelitis can be tolerable changes in fracture healing, which do not elicit lameness in dogs. In our clinical patients, combinations of the complications were frequently seen (Table 1). Such typical samples were: (1) slight malalignment combined with mild arthrosis of adjacent joint(s), or with hyperthrophic callus, and (2) delayed union combined with hyperthrophic callus, and with osteomyelitis, respectively. Our findings can serve as an incitement to continue further studying and evaluating of the incidence not only clinically, but also of radiologically apparent complications of fracture healing. Such type of studies could yield information about the potentiality to tolerate different radiographically apparent complications of healing in a given fracture. Among 19 cases of long bone fractures, in which animals showed lameness of different intensity, very good results of treatment were achieved in 12 cases, fair in 1 fracture case, and poor in 6 cases. These cases (Table 2) represent a typical sample of complications of long bone fracture healing, which are clinically apparent and usually cause lameness in dogs. It is obvious also from Table 2 that some types of complications of fracture healing do not occur apart from other complications. For example, delayed union in combination with hyperthrophic callus, or with osteomyelitis, as well as nonunion in combination with implant failure were observed.

The time from injury to fracture fixation ranged from day 0 (day of injury) to day 90 (median 2 days). Dependence between the results of therapy and the time from injury to fracture fixation was confirmed at the $5 \%$ level of significance. Complications of fracture healing were found mainly in the cases with an interval between injury and fracture fixation longer than 4 days $\left(\chi^{2}\right.$-test; $\left.p<0.01\right)$. Concerning dependence on the time from injury to fracture management, significant difference between fracture cases with functionally and radiographically excellent outcome and functionally excellent outcome was found $\left(\chi^{2}\right.$-test; $p<0.01)$. However, these complications accompanying the delay in fracture treatment were clinically tolerated in 36 cases of long bone fractures. We also found a significant difference $\left(\chi^{2}\right.$-test; $\left.p<0.01\right)$ evaluating dependence of outcome of treatment on accuracy of fragment reposition between fracture cases with functionally and radiographically excellent outcome and cases with functionally excellent outcome. Anatomic or more precise fracture reduction was manifested in better clinical results and lower number of radiographically evident complications.

\section{Komplikace hojení zlomenin dlouhých kostí končetin u psů: funkční a rentgenologická kritéria jejich hodnocení}

Cílem studie bylo nejen zjistit incidenci jak drobných, tak závažných komplikací v hojení fraktur dlouhých kostí končetin u psů, ale také určit procento rentgenologicky patrných komplikací, jež jsou pacienti schopni funkčně tolerovat. Byly sledovány klinické aspekty hojení zlomenin dlouhých kostí končetin u 200 psů léčených na Klinice chirurgie a ortopedie Veterinární a farmaceutické university v Brně od začátku ledna 1998 do konce června 1999. Léčbě zlomenin se podrobilo 156 psů se 164 frakturami. Tyto zlomeniny byly léčeny otevřenou $(86,59 \%$ případů fraktur) nebo uzavřenou $(13,41 \%)$ repozicí a vnitřnî fixací $(70,73 \%$ případů), zevní skeletní fixací $(25,61 \%$ ) či dlahováním končetiny $(3,66 \%$ ). Byly vytvořeny dvě skupiny klinických pacientů. Do skupiny I bylo zařazeno 64 psů, u nichž jsme údaje o výsledku operace získali pouze z dotazníku zaslaného majiteli. Výsledky léčby fraktur v této skupině pacientů byly výborné v 70,31\% případů, velmi dobré v 21,88 $\%$ a uspokojivé v $7,81 \%$ prrípadů. Ve skupině II bylo 92 psů se 100 zlomeninami dlouhých 
kostí končetin, o jejichž výsledku léčby byly k dispozici všechny potřebné informace vycházející jak z klinických, tak rentgenologických pooperačních vyšetření na naší klinice. Výsledky léčby zlomenin u pacientů ve skupině II byly výborné v celkem $81,00 \%$ případů, velmi dobré ve $12,00 \%$, uspokojivé v $1,00 \%$ a špatné u $6,00 \%$ ošetřených fraktur. Ve skupině II byly rovněž hodnoceny komplikace spojené s fixací uvedených fraktur. Komplikace doprovázely především ty případy zlomenin, u nichž byla doba od vzniku fraktury do její fixace delší, než 4 dny $\left(\chi^{2}\right.$-test; $\left.p<0.01\right)$. Psi, kteří po operaci nekulhali (s výborným výsledkem léčby) byli schopni co do funkce operované končetiny tolerovat rentgenologické abnormality související s léčbou dané zlomeniny ve 44,45\% případů (36 z 81 fraktur s výborným výsledkem terapie).

\section{References}

ARON, D. N., TOOMBS, J. P. 1984: Update on principles of external skeletal fixation. Comp. Cont. Edu. Pract. Vet. 6: $845-858$

BRINKER, W. O., HOHN, R. B., PRIEUR, W.D. 1984: Manual of internal fixation in small animals. SpringerVerlag Inc., New York, pp. 65-110

DE CAMP 1993: External coaptation. In: SLATTER, D: Textbook of Small Animal Surgery. $2^{\text {nd }}$ ed. W. B. Saunders, Philadelphia, pp. 1661-1676

GÁL, P. 1999: Úskalí, selhání a komplikace miniinvazivní osteosyntézy v dětské traumatologii. Úraz. Chir. 7: 1-8

GÁL, P., TECL, F., SKOTÁKOVÁ, J. 1999: Zlomeniny a fyzární poranění proximálního konce humeru u dětí. Acta Chir. Orthop. Traum. Čech. 66: 95-100

GÁL, P., NEČAS, A. 1999: Mininvazivní osteosyntéza při poranění laterální fýzy kondylu humeru u dětí. (Miniinvasive Osteosynthesis in Injuries of the Lateral Humeral Condyle in Children). Lék. obzor 48: 145-148

GUERIN, S.R., LEWIS, D.D., LANZ, O.I., STALLING, J.T. 1998: Comminuted supracondylar humeral fractures repaired with a modified type I external skeletal fixator construct. J. Small Anim. Pract. 39: 525-532

HULSE, D.A. 1997: Reduction in plate strain by addition of an intramedullary pin. Vet. Surg. 26: 451-459

HULSE, D.A., JOHNSON, A.L. 1999: Decision making in fracture management. In: FOSSUM, T.W.: Small Animal Surgery. Mosby-Year Book, Inc., St. Louis, pp. 730-733

JOHNSON, A. L., NEČAS, A., TOOMBS, J. P. 1998a: Biomechanika a techniky aplikace ESF na femur a humerus. (Biomechanics and Techniques of ESF Application - Femur and Humerus). In: NEČAS, A., TOOMBS, J. P., JOHNSON, A. L.: Zevní skeletní fixace a biologická léčba fraktur. (External Skeletal Fixation and Biologic Fracture Treatment) Vector, Brno, pp. 125-136

JOHNSON, A. L., NEČAS, A., TOOMBS, J. P. 1998b: Biomechanika a techniky aplikace ESF na radius/ulnu a tibii. (Biomechanics and Techniques of ESF Application - Radius/Ulna and Tibia). In: NEČAS, A., TOOMBS, J.P., JOHNSON, A. L.: Zevní skeletní fixace a biologická léčba fraktur. (External Skeletal Fixation and Biologic Fracture Treatment) Vector, Brno, pp. 92-103

JOHNSON, J.A., AUSTIN, C., BREUR, G.J. 1994: Incidence of canine appendicular musculoskeletal disorders in 16 veterinary teaching hospitals from 1980 through 1989. Vet. Comp. Orthop. Trauma 7: 56-69

MATOUŠKOVÁ, O., CHALUPA, J., CÍGLER, M, HRUŠKA, K. 1992: STAT plus - uživatelská př́ručka, VÚVeL Brno, $168 \mathrm{p}$.

MILLER, C.W., SUMNER-SMITH, G., SHERIDAN, C., PENNOCK, P.W. 1998: Using the Unger systém to classify 386 long bone fractures in dogs. J. Small Anim. Pract. 39: 390-393

MEYER-LINDENBERG, A., EBEL, H., FEHR, M. 1991: Fractures of the distal humerus - experiences with fracture classification according to Unger et al. (1990). Kleintierpraxis 36: 411-422

NEČAS, A. 1996: Zlomeniny kostí pánevní končetiny. (Fractures of the Hindlimb). Proceedings, IV. annual congress of CAVLMZ, Brno, October 11-12, pp. 52-60

SALTER, R.B., HARRIS, W.R. 1963: Injuries involving the epiphyseal plate. J. Bone Joint Surg. (Am) 45: $587-622$

STIGEN, Ø. 1999: Supracondylar femoral fractures in 159 dogs and cats treated using a normograde intramedullary pinning technique. J. Small Anim. Pract. 40: 519-523

ROBINS, G.M. 1998: Delayed union and nonunion. In: BRINKER, W.O., OLMSTEAD, M.L., SUMNERSMITH, G., PRIEUR, W.D.: Manual of internal fixation in small animals. $2^{\text {nd }}$ ed. Springer-Verlag, Berlin, pp. 227-239

UNGER, M.P., MONTAVON, M., HEIM, U.F.A. 1990: Classification of fractures of long bones in the dog and cat: Introduction and clinical application. Vet. Comp. Orthop. Traumat. 3: 41-50

WHITNEY, W.O., SCHRADER, S.C. 1987: Dynamic intramedullary crosspinning technique for repair of distal femoral fractures in dogs and cats: 71 cases (1981-1985). J. Am. Vet. Med. Assoc. 9: 1133-1138 